\title{
AS REPERCUSSÕES DA SENTENÇA JUDICIAL NO PROCESSO ADMINISTRATIVO E O NOVEL ENTENDIMENTO DO STF ALUSIVO À PENA DE PRISÃO DERIVANTE DE CONDENAÇÃO CRIMINAL EM SEGUNDA INSTÂNCIA
}

\author{
THE IMPACT OF COURT DECISIONS OVER ADMINISTRATIVE PROCESSES AND \\ THE NEW UNDERSTANDING OF THE SUPREME COURT REGARDING \\ IMPRISONMENT DUE TO CRIMINAL CONVICTION BY COURT OF APPEALS
}

André Dias Fernandes

\author{
Doutor em Direito do Estado pela USP. Mestre em Direito pela UFC. MBA em Poder \\ Judiciário pela FGV-Direito-Rio. Professor do Programa de Mestrado em Direito da UNI7 \\ e de outros cursos de pós-graduação. Juiz Federal em Fortaleza-CE. \\ E-mail: andredefernandes@gmail.com
}

Recebido em: 21/02/2017

Aprovado em: 02/10/2017

\begin{abstract}
RESUMO: A independência relativa entre as instâncias penal, civil e administrativa constitui temática naturalmente controvertida, designadamente por situar-se na zona de interseção entre o direito administrativo, civil e penal, envolvendo acesas discussões acerca da influência mútua entre estes ramos do direito. Decisões recentes do Supremo Tribunal Federal que restringiram o âmbito de proteção do direito fundamental consistente na presunção de não culpabilidade, afastando a necessidade de trânsito em julgado em matéria eleitoral para efeito de inelegibilidade e em matéria criminal para efeito de início de cumprimento de pena de prisão, suscitam a questão de saber se a decisão ainda não passada em julgado repercute na esfera administrativa, vinculando desde logo a decisão administrativa. Com fulcro numa análise sistemática e comparativa da doutrina, da jurisprudência e da legislação brasileira, italiana e espanhola, conclui-se pela ausência de vinculação formal ao acórdão condenatório ainda recorrível. Todavia, estima-se que, na prática, diante do elevado ônus argumentativo necessário para sobrepujar os fundamentos do acórdão e do reduzido índice de reforma dos acórdãos condenatórios para absolutórios, a tendência da autoridade administrativa seja a de aderir às razões adotadas no acórdão.
\end{abstract}

Palavras-chave: Processo administrativo. Repercussões da sentença. Presunção de não culpabilidade. Direito fundamental. Âmbito de proteção. Condenação em segunda instância.

ABSTRACT: The relative independence between the criminal, civil and administrative spheres is, by nature, a controversial subject, in particular because it is situated in the area of intersection between administrative, civil and criminal law, involving discussions about the mutual influence between these branches of law. Recent decisions of the Supreme Court that have restricted the scope of protection of the fundamental right consisting in the presumption of innocence, removing the need for res judicata in electoral matters regarding ineligibility and in criminal matters for the purpose of commencing prison sentences, raise the question as to whether the decision has not yet become final has repercussions at the administrative level, binding immediately the administrative decision. With a focus on a systematic and comparative analysis of the doctrine, jurisprudence and Brazilian, Italian and Spanish legislation, it is concluded that there is no formal bond to the condemnatory judgment still open to challenge. However, it is

Revista de Direito Brasileira | São Paulo, SP | v. 19 | n. 8 | p. 348 - 365 |Jan./Abr. 2018 
considered that, in practice, given the high burden of argument needed to overcome the grounds of the judgment and the low rate of reform of convictions to acquittals, the tendency of the administrative authority is to adhere to the reasons given in the judgment.

Keywords: Administrative process. Repercussions of the sentence. Presumption of innocence. Fundamental right. Scope of protection. Conviction by court of appeals.

SUMÁRIO: Introdução; 1 Panorama constitucional e legal; 2 Conduta única imputada consistente em crime, sem falta residual: desnecessidade de suspensão do processo administrativo; 3 Falta residual e súmula 18 do STF; 4 Sentença judicial e pena de cassação de aposentadoria; 5 Repercussão na esfera administrativa dos acórdãos penais condenatórios recorríveis; Conclusão; Referências Bibliográficas.

\section{INTRODUÇÃO}

É assente que uma mesma conduta humana pode constituir, simultaneamente, ilícito penal, civil e administrativo, ensejando sanções no âmbito criminal, civil e administrativo.

Todavia, a mesma conduta não pode ser objeto de sanções idênticas no mesmo âmbito, sob pena de configurar bis in idem. Portanto, uma mesma conduta não pode sofrer dúplice responsabilização no âmbito criminal: ninguém pode ser punido duas vezes pelo mesmo fato na esfera criminal. ${ }^{1} \mathrm{O}$ mesmo se dá nas esferas civil e administrativa.

Ademais, há atos que configuram, ao mesmo tempo, ilícito penal, civil e administrativo, assim como há atos que constituem mero ilícito administrativo, não configurando ilícito criminal ou civil (ilícitos administrativos puros). Os primeiros (ilícitos administrativos qualificados) revestem-se de maior gravidade do que os ilícitos administrativos puros, pois afetam não apenas o funcionamento da Administração, mas, igualmente, a própria sociedade, evidenciando uma periculosidade tanto interna como externa. $^{2}$

Outrossim, a independência das instâncias penal, civil e administrativa não é absoluta, mas relativa, de modo que o julgamento, em determinada esfera, do ilícito administrativo qualificado pode repercutir, em determinadas hipóteses e sob dadas circunstâncias, direta ou indiretamente, nas demais órbitas. Tais repercussões envolvem mais frequentemente o direito penal e o administrativo.

Nesse contexto, cumpre investigar se os acórdãos condenatórios em matéria penal (com natureza de sentença) ainda não transitados em julgado podem ou devem vincular a decisão na instância administrativa, tendo em vista o novo entendimento firmado em 17.02.2016 pelo Plenário do STF no julgamento do HC 126.292 (e reafirmado em 05.10.2016 no julgamento da medida cautelar nas ADCs 43 e 44, bem assim em 10.11.2016 no julgamento do ARE 964246, com repercussão geral), no sentido de que tais acórdãos autorizam o início da execução da pena privativa de liberdade antes mesmo do seu trânsito em julgado.

Impende, pois, analisar o âmbito de proteção do direito fundamental consistente na presunção constitucional de não culpabilidade, bem assim as principais repercussões da sentença judicial no processo administrativo.

\footnotetext{
${ }^{1}$ Obviamente, tal não obsta a que a lei imponha sanções diversas cumulativas para a mesma conduta na respectiva esfera, como, v.g., pena de prisão cumulada com pena de multa. O que não é admissível é que a mesma conduta humana seja punida duas ou mais vezes com a mesma sanção (ex: duas penas de prisão pelo mesmo homicídio).

${ }^{2}$ ARAÚJO, Edmir Netto de. Curso de Direito Administrativo. 7. ed. São Paulo: Saraiva, 2015, p. 1089.
}

Revista de Direito Brasileira | São Paulo, SP | v. 19 | n. 8 | p. 348 - 365 |Jan./Abr. 2018 


\section{PANORAMA CONSTITUCIONAL E LEGAL}

A relativa independência das instâncias é da tradição do nosso Direito. Embora sem nominá-la explicitamente, a $\mathrm{CF} / 88$ a agasalha, ao menos em parte, ao prever sanções penais, civis e administrativas para atos lesivos à probidade administrativa e ao meio ambiente:

Art. 37. [...] $\S 4^{\circ}$. Os atos de improbidade administrativa importarão a suspensão dos direitos políticos, a perda da função pública, a indisponibilidade dos bens e o ressarcimento ao erário, na forma e gradação previstas em lei, sem prejuízo da ação penal cabível.

Art. 225. [...] $\S 3^{\circ}$. As condutas e atividades consideradas lesivas ao meio ambiente sujeitarão os infratores, pessoas físicas ou jurídicas, a sanções penais e administrativas, independentemente da obrigação de reparar os danos causados.

No plano infraconstitucional, dispõe o art. 935 do CC/2002:

Art. 935. A responsabilidade civil é independente da criminal, não se podendo questionar mais sobre a existência do fato, ou sobre quem seja o seu autor, quando estas questões se acharem decididas no juízo criminal.

Por seu turno, prescrevem os arts. 63, 65, 66 e 67 do CPP:

Art. 63. Transitada em julgado a sentença condenatória, poderão promover-lhe a execução, no juízo cível, para o efeito da reparação do dano, o ofendido, seu representante legal ou seus herdeiros.

Parágrafo único. Transitada em julgado a sentença condenatória, a execução poderá ser efetuada pelo valor fixado nos termos do inciso IV do caput do art. 387 deste Código sem prejuízo da liquidação para a apuração do dano efetivamente sofrido. (Incluído pela Lei no 11.719, de 2008).

Art. 65. Faz coisa julgada no cível a sentença penal que reconhecer ter sido o ato praticado em estado de necessidade, em legítima defesa, em estrito cumprimento de dever legal ou no exercício regular de direito.

Art. 66. Não obstante a sentença absolutória no juízo criminal, a ação civil poderá ser proposta quando não tiver sido, categoricamente, reconhecida a inexistência material do fato.

Art. 67. Não impedirão igualmente a propositura da ação civil:

I - o despacho de arquivamento do inquérito ou das peças de informação;

II - a decisão que julgar extinta a punibilidade;

III - a sentença absolutória que decidir que o fato imputado não constitui crime.

Por sua vez, prevê a Lei 8.112/90:

Art. 125. As sanções civis, penais e administrativas poderão cumular-se, sendo independentes entre si.

Art. 126. A responsabilidade administrativa do servidor será afastada no caso de absolvição criminal que negue a existência do fato ou sua autoria.

Por fim, o art. 386 do CPP enumera as hipóteses de absolvição do réu:

Art. 386. O juiz absolverá o réu, mencionando a causa na parte dispositiva, desde que reconheça:

I - estar provada a inexistência do fato;

II - não haver prova da existência do fato;

III - não constituir o fato infração penal; 
IV - estar provado que o réu não concorreu para a infração penal; (Redação dada pela Lei $\mathrm{n}^{\circ} 11.690$, de 2008)

V - não existir prova de ter o réu concorrido para a infração penal; (Redação dada pela Lei $\mathrm{n}^{\mathrm{o}} 11.690$, de 2008)

VI - existirem circunstâncias que excluam o crime ou isentem o réu de pena (arts. 20, 21, 22, 23, 26 e $\S 1^{\circ}$ do art. 28, todos do Código Penal), ou mesmo se houver fundada dúvida sobre sua existência; (Redação dada pela Lei $n^{\circ} 11.690$, de 2008)

VII - não existir prova suficiente para a condenação. (Incluído pela Lei $n^{\circ}$ 11.690, de 2008)

Ademais, os arts. 91 e 92 do CP atribuem à sentença condenatória criminal efeitos nas órbitas civil e administrativa, dentre os quais avulta "a perda de cargo, função pública ou mandato eletivo" (CP, art. 92, I). ${ }^{3}$

Portanto, como se infere dos dispositivos acima transcritos, há hipóteses legais de comunicabilidade entre a instância criminal e a instância administrativa. Há hipóteses de absolvição comunicáveis e hipóteses de absolvição não comunicáveis.

Nos casos de condenação criminal (que pressupõe o reconhecimento da materialidade do fato e da autoria), há repercussão na decisão administrativa por proferir ou que já tenha sido proferida: a decisão administrativa sobre os mesmos fatos tem de adequar-se à sentença condenatória transitada em julgado. Assim, se a decisão administrativa foi de absolvição, terá de ser revista, pois, como acentua Edmir Netto de Araújo, "nessa hipótese a Administração não pode decidir de maneira diversa, ou seja, não pode absolver de faltas administrativas que, na esfera penal, tenham sido objeto de condenação pelos mesmos fatos". 4

No pertinente às sentenças penais absolutórias, Maria Sylvia Zanella Di Pietro considera que repercutem na esfera administrativa as hipóteses de absolvição previstas nos incisos I, IV (com esteio no art. 935 do CC/2002) e VI (com espeque no art. 65 do CPP). Estima que a hipótese do inciso III ("não constituir o fato infração penal") não repercute porque o fato pode não constituir crime, mas configurar ilícito administrativo, que é um minus em relação àquele. Outrossim, sustenta que as hipóteses previstas nos incisos II, V e VII, “em que a absolvição se dá por falta de provas", são equiparáveis entre si quanto aos efeitos. ${ }^{5}$

Contudo, Edmir Netto de Araújo diverge quanto ao inciso V ("não existir prova de ter o réu concorrido para a infração penal"), à consideração de que uma coisa é a inexistência de qualquer prova de que o réu tenha concorrido para o crime (como está previsto no inciso V), e outra coisa bem diversa é a insuficiência de prova de que o réu tenha concorrido para o crime. No primeiro caso, não haveria prova alguma, frágil ou robusta, ao passo que, no segundo caso, haveria prova, mas insuficiente, frágil, incapaz de embasar por si só a condenação criminal. Portanto, segundo ele, tais hipóteses não são assimiláveis entre si, de modo que a sentença

\footnotetext{
3 “Art. 92. São também efeitos da condenação:

I - a perda de cargo, função pública ou mandato eletivo: (Redação dada pela Lei n ${ }^{\circ} 9.268$, de $1^{\circ}$.4.1996)

a) quando aplicada pena privativa de liberdade por tempo igual ou superior a um ano, nos crimes praticados com abuso de poder ou violação de dever para com a Administração Pública; (Incluído pela Lei no 9.268, de $1^{\circ}$.4.1996)

b) quando for aplicada pena privativa de liberdade por tempo superior a 4 (quatro) anos nos demais casos. (Incluído pela Lei $\mathrm{n}^{\circ} 9.268$, de $\left.1^{\circ} .4 .1996\right)$

II - a incapacidade para o exercício do pátrio poder, tutela ou curatela, nos crimes dolosos, sujeitos à pena de reclusão, cometidos contra filho, tutelado ou curatelado;

III - a inabilitação para dirigir veículo, quando utilizado como meio para a prática de crime doloso.

Parágrafo único. Os efeitos de que trata este artigo não são automáticos, devendo ser motivadamente declarados na sentença."

${ }^{4}$ ARAÚJO, Edmir Netto de. Curso de Direito Administrativo. 7. ed. São Paulo: Saraiva, 2015, p. 1093.

${ }^{5}$ DI PIETRO, Maria Sylvia Zanella. Curso de Direito Administrativo. 28. ed. São Paulo: Atlas, 2015, p. 759. Nessa linha, admitindo a comunicação no tocante ao inciso II do art. 386 do CPP ("não haver prova da existência do fato"), cf. RMS 34041 AgR, Rel. Min. Teori Zavascki, Segunda Turma, julgado em 29/03/2016, DJe 28/04/2016.
}

Revista de Direito Brasileira | São Paulo, SP | v. 19 | n. 8 | p. 348 - 365 |Jan./Abr. 2018 
absolutória fundada no inciso $\mathrm{V}$ repercute integralmente na esfera administrativa, porque, em última análise, redunda na negação da autoria. ${ }^{6}$

Quanto ao reconhecimento na sentença penal da existência de excludentes do crime previstas no inciso VI, o art. 65 do CPP refere que fará coisa julgada no cível, não mencionando a instância administrativa. Todavia, a ratio subjacente é a mesma quanto à esfera administrativa, até porque o próprio $\mathrm{CP}$ define tais excludentes como causas de "exclusão de ilicitude" (CP, art. 23), e se excluem a ilicitude penal (CP, art. 23) e civil (CPP, art. 65), não haveria por que subsistir uma ilicitude meramente administrativa. Em verdade, a própria doutrina penal afirma que constituem "excludentes de antijuridicidade", ou seja, os atos praticados com base nelas não são antijurídicos, não são contrários ao Direito como um todo (a abranger todos os respectivos ramos). ${ }^{7}$

No pertencente às causas de isenção de pena, também contempladas no inciso VI do art. 385 do CPP, podem repercutir na órbita administrativa, a depender da situação concreta. Por exemplo, na coação irresistível e na estrita obediência a ordem não manifestamente ilegal de superior hierárquico, há comunicabilidade entre as instâncias, visto que só podem ser punidos os autores da coação ou da ordem (CP, art. 22); nos casos de alienação mental (CP, art. 26) poderá haver repercussão na esfera administrativa, inclusive para efeito de readaptação ou aposentadoria por invalidez do servidor; na situação de embriaguez derivante de força maior haverá repercussão na esfera administrativa, pois equipole à coação irresistível, mas na embriaguez adveniente de caso fortuito poderá subsistir uma punição administrativa residual, malgrado a absolvição na esfera penal; nos casos de erro de fato ou sobre a ilicitude do fato, também será possível a existência de uma falta residual punível administrativamente, a depender das circunstâncias do caso.

Por fim, é digna de registro a posição de Romeu Felipe Bacellar Filho. Deplorando a interpretação dada ao art. 126 da Lei 8.112/90 pela doutrina e jurisprudência majoritárias, o autor sustém que a sentença penal absolutória transitada em julgado sempre deve repercutir no processo administrativo, qualquer que seja o fundamento invocado para absolvição (falta de provas, extinção da punibilidade por prescrição, etc.), uma vez que deve ser emprestada interpretação conforme à Constituição ao art. 126 da Lei 8.112/90, a fim de harmonizá-lo com o princípio constitucional da presunção de inocência, evitando-se assim uma "uma distinção hierárquica entre as sentenças penais absolutórias". ${ }^{8}$

\footnotetext{
6 "Não se trata de existir ou não prova suficiente para a condenação, mas da inexistência (é o que o dispositivo do CPP, art. 386, V, atual, diz) de quaisquer provas de que o réu praticou a infração penal. Ora, se não concorreu, obviamente também não praticou o fato, ou seja, se a sentença assim o reconheceu, juridicamente não foi o indigitado o autor da infração (negação da autoria), repercutindo integralmente a sentença penal absolutória na decisão disciplinar." (ARAÚJO, Edmir Netto de. Curso de Direito Administrativo. 7. ed. São Paulo: Saraiva, 2015, p. 1095.) (Grifos do original.)

Reconhecendo que a presença de excludente de antijuridicidade repercute na via administrativa, já decidiu o Plenário do STF: “[...] As sanções penais e administrativas, qualificando-se como respostas autônomas do Estado à prática de atos ilícitos cometidos pelos servidores públicos, não se condicionam reciprocamente, tornando-se possível, em consequência, a imposição da punição disciplinar independentemente de prévia decisão da instância penal. Com a só exceção do reconhecimento judicial da inexistência de autoria ou da inocorrência material do próprio fato, ou, ainda, da configuração das causas de justificação penal, as decisões do Poder Judiciário não condicionam o pronunciamento censório da Administração Pública, Precedentes. [...]” (MS 21029, Rel. Min. Celso de Mello, Tribunal Pleno, julgado em 15/06/1994, DJ 23/09/1994, p. 25326) (Grifou-se.) Na mesma linha, tem decidido o STJ: "A sentença penal absolutória que reconhece a ocorrência de causa excludente de ilicitude (estado de necessidade) faz coisa julgada no âmbito administrativo, sendo incabível a manutenção de pena de demissão baseada exclusivamente em fato que se reconheceu, em decisão transitada em julgado, como lícito." (REsp 1090425/AL, Rel. Min. Maria Thereza Moura, $6^{a}$ Turma, julgado em 01/09/2011, DJe 19/09/2011). Na mesma linha: ARAÚJO, Edmir Netto de. Curso de Direito Administrativo. 7. ed. São Paulo: Saraiva, 2015, p. 1095.

8 "Quanto ao art. 126, o fato de o legislador não ter feito menção à absolvição por insuficiência de provas ou, mesmo, à extinção da punibilidade pela prescrição, não quer significar que as sentenças penais absolutórias alicerçadas nesses fundamentos não devam repercutir sobre a eventual aplicação de sanção no processo disciplinar. [...] Aceitar Revista de Direito Brasileira | São Paulo, SP | v. 19 | n. 8 | p. 348 - 365 |Jan./Abr. 2018
} 


\section{CONDUTA ÚNICA IMPUTADA CONSISTENTE EM CRIME, SEM FALTA RESIDUAL: DESNECESSIDADE DE SUSPENSÃO DO PROCESSO ADMINISTRATIVO}

Por vezes, a lei estatutária descreve, como causa de demissão por meio de processo administrativo, a prática de "ato definido como crime" ou de "crime", sem enunciá-lo autonomamente, a exemplo do art. 132, I, da Lei 8.112/90. Outras vezes, a lei estatutária define como ilícito passível de demissão o cometimento de atos que constituem crimes, descrevendo-os autonomamente.

Caso não haja a imputação de nenhuma falta administrativa residual punível, deverá o processo administrativo ficar sobrestado à espera da decisão no juízo criminal sobre a existência de crime? Somente o juízo criminal tem competência para decidir sobre a existência de crime, mesmo para efeito de aplicação da pena administrativa de demissão?

Segundo Hely Lopes Meirelles", "se a punição estiver fundamentada na 'prática de crime contra a Administração Pública, este há que estar afirmado em sentença transitada em julgado'."

Maria Sylvia Zanella Di Pietro ${ }^{10}$ parece seguir linha similar, com aludir à Formulação 128 do extinto $\mathrm{DASP}^{11}$, órgão este que negava a possibilidade de demissão quando o ato constituísse crime não descrito autonomamente na lei estatutária (como o atual art. 132, I, da Lei n. ${ }^{\circ}$ 8.112/90), mas admitia a demissão quando o fato criminoso fosse autonomamente descrito na lei estatutária.

Para Romeu Felipe Bacellar Filho ${ }^{12}$, caso o servidor esteja sendo acusado de ter perpetrado um crime que constitua "na exatidão e proporção" também falta funcional, "o processo administrativo deverá aguardar a solução definitiva do processo criminal, e, concluindose pela absolvição do acusado com base em qualquer fundamento que se adote, ele necessariamente será absolvido no processo disciplinar", tendo em vista os princípios da presunção de inocência e da dignidade da pessoa humana.

Diversamente, Edmir Netto de Araújo perfilha opinião de que, embora seja possível ( $e$ até mesmo conveniente em determinados casos) a suspensão do processo administrativo enquanto a existência do crime não é decidida no juízo criminal, a Administração não está obrigada a sobrestar o processo administrativo.

que as duas modalidades de decisão absolutória - por falta de provas e pela negativa do fato ou de sua autoria possam produzir efeitos jurídicos distintos ao acusado, negando-se a condição de inocente ao réu absolvido por insuficiência probatória ou por extinção da punibilidade pela prescrição, significaria fazer tabula rasa da presunção constitucional de inocência. A interpretação da legislação ordinária conforme a Constituição autoriza afirmar seguramente que, independentemente do fundamento, havendo absolvição - seja por negativa do fato ou da autoria, seja por falta de provas - o acusado se presumirá indubitavelmente inocente, por força do princípio constitucional da presunção de inocência. Destarte, se houver coincidência de objetos entre o processo criminal e o processo administrativo disciplinar, este deverá aguardar a decisão irrecorrível daquele, para então concluir pela condenação ou absolvição do acusado, conforme a decisão exarada na esfera jurisdicional, independentemente da motivação." (BACELLAR FILHO, Romeu Felipe. O Mensalão e a propalada independência das instâncias. Revista dos Tribunais, São Paulo, v. 933, p. 445-454, jul. 2013.)

${ }^{9}$ MEIRELLES, Hely Lopes. Curso de Direito Administrativo brasileiro. 38. ed. São Paulo: Malheiros, 2012 , p. 556.

${ }^{10}$ DI PIETRO, Maria Sylvia Zanella. Curso de Direito Administrativo. 28. ed. São Paulo: Atlas, 2015 , p. $760-761$.

11 "Não pode haver demissão com base no item I, do art. 207, do Estatuto dos Funcionários [correspondente ao art. 132, I, da Lei n. $\left.{ }^{\circ} 8.112 / 90\right]$, se não a precede condenação criminal."

12 BACELLAR FILHO, Romeu Felipe. O Mensalão e a propalada independência das instâncias. Revista dos Tribunais, São Paulo, v. 933, p. 445-454, jul. 2013.

Revista de Direito Brasileira | São Paulo, SP | v. 19 | n. 8 | p. 348 - 365 |Jan./Abr. 2018 
No direito italiano, também se reconhece à Administração a faculdade - e não o dever - de suspender o processo administrativo em razão da pendência de processo penal em que se apurem os mesmos fatos, tendo em vista a independência entre as instâncias penal e administrativa e a possibilidade de a autoridade administrativa apreciar se determinados fatos são criminosos ou não para efeito de imposição de sanção disciplinar. ${ }^{13}$ Esta posição conta com o apoio da jurisprudência do STF, inclusive reafirmada recentemente em RE com repercussão geral:

SERVIDOR PÚBLICO. Policial Militar. Processo administrativo. Falta disciplinar. Exclusão da corporação. Ação penal em curso, para apurar a mesma conduta. Possibilidade. Independência relativa das instâncias jurisdicional e administrativa. Precedentes do Pleno do STF. Repercussão geral reconhecida. Jurisprudência reafirmada. Recurso extraordinário a que se nega provimento. Apresenta repercussão geral o recurso que versa sobre a possibilidade de exclusão, em processo administrativo, de policial militar que comete faltas disciplinares, independentemente do curso de ação penal instaurada em razão da mesma conduta. (ARE 691306 RG, Rel. Min. Cezar Peluso, julgado em 23/08/2012, REPERCUSSÃO GERAL-MÉRITO, DJe 1009-2012) (Grifou-se.) ${ }^{14}$

Consoante o STF, a presunção constitucional de não culpabilidade $\left(\mathrm{CF} / 88\right.$, art. $5^{\circ}$, LVII $^{15}$ ) não obsta a que a autoridade administrativa aplique a pena de demissão antes de decisão do juízo criminal sobre a existência ou não do crime, visto que tal princípio constitucional tem seu raio de incidência circunscrito ao próprio direito penal, não alcançando o direito disciplinar. Assim, ninguém poderia ser considerado culpado até o trânsito em julgado de sentença penal condenatória tão somente para efeitos criminais (inversão de onus probandi no processo criminal, etc.), não vinculando a autoridade administrativa, que poderia considerar o servidor culpado de crime para efeito de punição administrativa, sem vulnerar o disposto no art. 5', LVII, da CF/88. Nesse sentido:

Demissão de funcionário estável, mediante processo administrativo, por crime contra a administração pública: validade: análise de jurisprudência e doutrina. 1 . Se o fato único imputado ao funcionário constitui crime contra a administração pública, essa é também a única e exclusiva capitulação legal, que lhe corresponde, no rol das infrações disciplinares sujeitas à pena de demissão. 2.

\footnotetext{
${ }^{13}$ Nesse sentido: "In ossequio al principio, accolto dal nuovo codice di procedura penale, della separatezza e autonomia tra giudizio penale e giudizio amministrativo, il giudice amministrativo può risolvere incidenter tantum le pregiudiziali penali e ha, quindi, la facoltà - e non il dovere - di sospendere il processo quando ritenga che i fatti accertati in un giudizio penale pendente possano essere rilevanti ai fini della decisione." (CASETTA, Elio. Manuale di diritto amministrativo. 13. ed. Milano: Giuffrè, 2011, p. 877.) Cf. também: DI GIACOMO, Lorenzo. Gli incidenti nel processo e l'estinzione del giudizio. In: FRENI, Federico: CLARIZIA, Paolo (Coords.). Il processo amministrativo nella giurisprudenza. Commento sistematico ai principali istituti. Testo aggiornato al decreto correttivo al Codice del Processo Amministrativo (d.lgs. 15 novembre 2011, n.195). Milano: Giuffrè, 2012, p. 188189.

${ }^{14} \mathrm{Na}$ mesma linha: "Processo administrativo disciplinar. Ausência de obrigatoriedade de decisão judicial em processo de improbidade administrativa para aplicação da sanção de demissão. Sanção aplicada de acordo com a apuração dos fatos no âmbito do processo administrativo disciplinar. [...] 1. A jurisprudência da Suprema Corte é pacífica no sentido da independência entre as instâncias cível, penal e administrativa, não havendo que se falar em violação dos princípios da presunção de inocência e do devido processo legal pela aplicação de sanção administrativa por descumprimento de dever funcional fixada em processo disciplinar legitimamente instaurado antes de finalizado o processo cível ou penal em que apurados os mesmos fatos. Precedentes. [...]" (RMS 28919 AgR, Rel. Min. Dias Toffoli, Primeira Turma, julgado em 16/12/2014, DJe 12-02-2015.) Similarmente: MS 26510, Rel. Min. Cezar Peluso, Tribunal Pleno, julgado em 17/02/2010.

15 “Art. $5^{\circ}$. [...] LVII - ninguém será considerado culpado até o trânsito em julgado de sentença penal condenatória".
}

Revista de Direito Brasileira | São Paulo, SP | v. 19 | n. 8 | p. 348 - 365 |Jan./Abr. 2018 
Não obstante, é firme a jurisprudência do STF, com o melhor respaldo doutrinário, no sentido de que a demissão do funcionário público motivada pela prática de crime funcional pode fazer-se mediante processo administrativo, decidido antes da solução do processo penal pelo mesmo fato; esse entendimento não é afetado pela superveniência da presunção constitucional de não culpabilidade (CF, art. $5^{\circ}$, LVII).

(STF, MS 21294, Rel. Min. Sepúlveda Pertence, Tribunal Pleno, julgado em 23/10/1991, DJ 21-09-2001) (Grifou-se.)

Tal compreensão acerca do âmbito de proteção da presunção de inocência foi ratificada no julgamento da "Lei da Ficha Limpa", ocasião em que se entendeu que tal "princípio" não impedia que decisões judiciais condenatórias ainda não transitadas em julgado servissem para embasar inelegibilidade. ${ }^{16}$ Nesse julgamento, a presunção de não culpabilidade prevista no art. 5. ${ }^{\circ}$, LVII, da CF/88 foi tratada como norma-regra (e não como norma-princípio, ou "mandamento de otimização", na expressão de Alexy ${ }^{17}$ ), reconhecendo-lhe o STF um âmbito de proteção mais reduzido do que até então lhe vinha atribuindo em julgados anteriores. Destarte, recorrendo ao método da redução teleológica, o STF rejeitou, na oportunidade, a "eficácia irradiante" antes reconhecida à presunção de não culpabilidade, afastando a sua incidência em matéria eleitoral nas hipóteses de inelegibilidade. ${ }^{18}$

Todavia, é certo que a decisão administrativa poderá ter de adequar-se ao que for decidido, ulteriormente, na sentença transitada em julgado.

\section{FALTA RESIDUAL E SÚMULA 18 DO STF}

Nem sempre há total coincidência entre o ilícito penal e o administrativo, de modo que é perfeitamente possível que remanesça um ilícito administrativo puro (falta residual ou resíduo heterogêneo) após a absolvição do crime pela sentença penal, a possibilitar a punição do responsável na instância administrativa. Nessa linha, prevê a Súmula 18 do STF: "Pela falta residual, não compreendida na absolvição pelo juízo criminal, é admissível a punição administrativa do servidor público".

A falta residual pode resultar também de uma absolvição penal não comunicável à esfera administrativa (resíduo homogêneo). ${ }^{19}$ Assim, a falta residual nem sempre será um ilícito

\footnotetext{
${ }^{16}$ A natureza jurídica da presunção de não culpabilidade é controvertida na doutrina, havendo quem não a considere autêntica presunção iuris tantum, visto que não há nenhuma evidência empírica de que a maioria dos acusados seja realmente inocente. Nessa linha: "A presunção de inocência se desconecta da verdade e se encaminha à proteção de outros valores. Não parece que haja regra de experiência que leve o legislador a pensar que, em geral, os acusados são inocentes. A presunção de inocência não está fundada sobre uma probabilidade empírica de condenação, mas constitui regra de dever ser, que conduz o legislador a estabelecer uma garantia processual dirigida a proteger valores ideológicos ou políticos e técnicos." (BRASIL, Deilton Ribeiro. A garantia do princípio constitucional da presunção de inocência (ou de não culpabilidade): um diálogo com os direitos e garantias fundamentais. Revista de Direito Brasileira, São Paulo, v. 15, n. 6, p. 376-398, set./dez. 2016, p. 382.)

${ }^{17}$ ALEXY, Robert. Teoria dos direitos fundamentais. Trad. Virgílio Afonso da Silva. São Paulo: Malheiros, 2008, p. 90. Acerca da distinção entre regras e princípios, cf. ainda: ÁVILA, Humberto. Teoria dos princípios: da definição à aplicação dos princípios jurídicos. 14. ed. São Paulo: Malheiros, 2013, p. 203-204; SILVA, Virgílio Afonso da. Direitos fundamentais: conteúdo essencial, restrições e eficácia. 2. ed. São Paulo: Malheiros, 2014, p. 43-64.

18 “A presunção de inocência consagrada no art. $5^{\circ}$, LVII, da Constituição Federal deve ser reconhecida como uma regra e interpretada com o recurso da metodologia análoga a uma redução teleológica, que reaproxime o enunciado normativo da sua própria literalidade, de modo a reconduzi-la aos efeitos próprios da condenação criminal (que podem incluir a perda ou a suspensão de direitos políticos, mas não a inelegibilidade), sob pena de frustrar o propósito moralizante do art. 14, § $9^{\circ}$, da Constituição Federal. [...]” (ADI 4578, Rel. Min. Luiz Fux, Tribunal Pleno, julgado em 16/02/2012.) (Grifou-se.)

${ }_{19}$ "A absolvição criminal não comunicável equivale a deixar a falta como residual, integralmente." (ARAÚJO, Edmir Netto de. Curso de Direito Administrativo. 7. ed. São Paulo: Saraiva, 2015, p. 1102.) (Grifou-se.)
}

Revista de Direito Brasileira | São Paulo, SP | v. 19 | n. 8 | p. 348 - 365 |Jan./Abr. 2018 
administrativo puro, podendo ser também um ilícito criminal (e, simultaneamente, administrativo) em relação ao qual a sentença penal não pôde repercutir na esfera administrativa, como ocorre, e.g., na hipótese de sentença penal absolutória por insuficiência de prova (CPP, art. 386, VII), competindo assim à autoridade administrativa punir tal ilícito administrativo qualificado. Segundo Cretella Júnior, a súmula 18 do STF se aplica tanto ao resíduo homogêneo como ao heterogêneo. ${ }^{20}$

\section{SENTENÇA JUDICIAL E PENA DE CASSAÇÃO DE APOSENTADORIA}

A pena de cassação de aposentadoria está prevista na Lei $8.112 / 90^{21}$ e vem sendo considerada constitucional pelo STF e pelo STJ, mesmo após a EC 20/98, que estatuiu o regime contributivo da Previdência Social do servidor público. ${ }^{22}$

Dissonando, porém, de sua jurisprudência tradicional ${ }^{23}$, a $2^{\mathrm{a}}$ turma do STF reconheceu no RE 610.290/MS a constitucionalidade do art. 117 da Lei Complementar n. ${ }^{\circ}$ 53/90, do Estado do Mato Grosso do Sul, que prevê uma pensão para os dependentes do policial militar excluído da corporação, tendo em vista o caráter contributivo da Previdência Social após a EC 20/98. ${ }^{24}$

Embora o acórdão trate especificamente de pensão, e não de aposentadoria propriamente dita, o fundamento invocado serviria para ambas as hipóteses. A matéria deverá ser pacificada quando do julgamento da ADI 4882, Rel. Min. Gilmar Mendes, na qual se alega a inconstitucionalidade dos arts. 127, IV, e 134 c/c 142, I, $\S 1^{\circ}$, da Lei 8.112/90. A ADPF 418, Rel. Min. Alexandre de Moraes, também versa o mesmo tema. Nas duas ações (ADI 4882 e ADPF 418), o Procurador-Geral da República opinou pela constitucionalidade da pena de cassação da aposentadoria, à consideração de que o servidor público está sujeito a dois regimes jurídicos relativamente autônomos (o estatutário e o previdenciário) e a pena de cassação integra o regime estatutário, não podendo a referida penalidade disciplinar ser invalidada com fundamento em normas atinentes ao regime previdenciário do servidor. ${ }^{25}$

20 CRETELLA JÚNIOR, José. Do ilícito administrativo. Disponível em: <http://www.revistas.usp.br/rfdusp/article/viewFile/66693/69303>. Acesso em: 17 jan. 2017.

21 “Art. 127. São penalidades disciplinares: [...] IV - cassação de aposentadoria ou disponibilidade. [...] Art. 134. Será cassada a aposentadoria ou a disponibilidade do inativo que houver praticado, na atividade, falta punível com a demissão."

22، A despeito das teses que se tem levantado acerca da inconstitucionalidade da aplicação da pena de cassação de aposentadoria de servidor público em processo administrativo disciplinar, seja em razão do caráter contributivo dos benefícios previdenciários, seja à luz dos princípios do direito adquirido e do ato jurídico perfeito, prevalece nesta Corte e no Supremo Tribunal Federal o entendimento de que é possível a aplicação da referida pena, desde que haja expressa previsão legal e que o ilícito administrativo tenha sido cometido pelo servidor ainda na atividade. 2. A sentença proferida no âmbito criminal somente repercute na esfera administrativa quando reconhecida a inexistência material do fato ou a negativa de sua autoria." (STJ, RMS 27.216/RJ, Rel. Min. Rogerio Schietti, 6a Turma, julgado em 28/04/2015, DJe 07/05/2015)

23 “[...] Militar estadual. Reserva remunerada. Condenação penal por crime cometido em atividade. Cassação da aposentadoria. [...] 4. A Corte já se pronunciou no sentido da possibilidade de cassação da aposentadoria, em que pese o caráter contributivo do benefício previdenciário. [...]" (ARE 892262 AgR, Rel. Min. Toffoli, 2a Turma, julgado em 05/04/2016, DJe 11-05-2016.) (Grifou-se.) Na mesma linha: RE 848019 AgR, Rel. Min. Teori Zavascki, $2^{\mathrm{a}}$ Turma, julgado em 16/09/2016, DJe 03-10-2016.)

24 "O benefício previdenciário instituído em favor dos dependentes de policial militar excluído da corporação representa uma contraprestação às contribuições previdenciárias pagas durante o período efetivamente trabalhado. III - Recurso extraordinário ao qual se nega provimento, assentando-se a constitucionalidade do art. 117 da Lei Complementar Estadual 53/1990." (RE 610290, Rel. Min. Lewandowski, Segunda Turma, julgado em 25/06/2013, DJe 15-08-2013.)

${ }^{25}$ Eis um excerto do Parecer ministerial na ADPF 418: "A cassação de aposentadoria e de disponibilidade, como penalidade disciplinar, integra o regime estatutário dos servidores públicos. Não cabe cogitar dos reflexos previdenciários da aposentadoria como fundamento para invalidar norma atinente ao regime disciplinar do funcionalismo público em sentido amplo (abrangendo agentes políticos como membros do Judiciário e do Ministério Público). A possibilidade de cassação de aposentadoria ou de disponibilidade é sanção correspondente à demissão

Revista de Direito Brasileira | São Paulo, SP | v. 19 | n. 8 | p. 348 - 365 |Jan./Abr. 2018 
De fora parte a discussão acerca da sua (in)constitucionalidade, certo é que a pena de cassação de aposentadoria não se insere entre os efeitos da condenação penal previstos nos arts. 91 e 92 do CP. Portanto, como não há previsão legal desse efeito extrapenal da sentença criminal e é inadmissível o emprego de analogia in malam partem em matéria penal, a pena de cassação de aposentadoria não pode decorrer de sentença criminal, não podendo esta, por conseguinte, repercutir no processo administrativo nesse tocante. Assim há entendido o STJ. ${ }^{26}$

A doutrina penal, em geral, tem sufragado o mesmo entendimento. ${ }^{27}$

A pena de cassação da aposentadoria também não está incluída no rol taxativo de sanções contempladas na Lei de Improbidade Administrativa (Lei 8.429/92). Logo, a sentença em ação de improbidade administrativa não pode determinar a cassação da aposentadoria, mas, administrativamente, poderá haver a cassação da aposentadoria, nos termos da Lei 8.112/90 ou da legislação estatutária estadual de regência. Portanto, eventual sentença condenatória por ato de improbidade administrativa não terá repercussão no processo administrativo no tocante à pena de cassação de aposentadoria.

\section{REPERCUSSÃO NA ESFERA ADMINISTRATIVA DOS ACÓRDÃOS PENAIS CONDENATÓRIOS RECORRÍVEIS}

O novel entendimento firmado em 17.02.2016 pelo Plenário do STF no julgamento do HC 126.292 (e ratificado em 05.10.2016 no julgamento da medida cautelar nas ADCs 43 e 44, bem como em 10.11.2016 no julgamento do ARE 964246, com repercussão geral $^{28}$ ), no sentido de que os acórdãos penais condenatórios recorríveis ensejam o início da execução da pena privativa de liberdade ${ }^{29}$ suscita a momentosa questão de saber se a autoridade administrativa

\footnotetext{
administrativa (inclusive a daquele que já tenha implementado os requisitos legais de aposentação, mas permaneça em atividade), em que o servidor igualmente perde, de forma proporcional ou total, a expectativa de retribuição decorrente das contribuições que fez ao longo da vida funcional. O mesmo ocorre, mutatis mutandis, na demissão decorrente de decisão judicial em ação específica (como a ação de improbidade administrativa) ou em processo criminal; neste caso, por força do art. 92, I, do Código Penal. De forma análoga, não há inconstitucionalidade nesses institutos, pois a perda do cargo ou função pública acarreta rompimento dos vínculos previdenciários, causado por ato ilícito do próprio servidor."

${ }^{26}$ Cf. REsp 1317487/MT, Rel. Min. Laurita Vaz, $5^{\text {a }}$ turma, julgado em 07/08/2014, DJe 22/08/2014. Na mesma linha: AgRg no REsp 1447549/GO, Rel. Min. Reynaldo Fonseca, $5^{\text {a }}$ turma, julgado em 03/03/2016, DJe 09/03/2016.

27 "A aposentadoria, que é direito a inatividade remunerada, não é abrangida pelo disposto no art. 92. A condenação criminal, portanto, somente afeta o servidor ativo, ocupante efetivo de cargo, emprego, função ou mandato eletivo. Caso já tenha passado à inatividade, não mais estando em exercício, não pode ser afetado por condenação criminal, ainda que esta advenha de fato cometido quando ainda estava ativo. Se for cabível, a medida de cassação da aposentadoria deve dar-se na órbita administrativa, não sendo atribuição do juiz criminal." (NUCCI, Guilherme de Souza. Código Penal comentado. 10. ed. São Paulo: RT, 2010, p. 525).

28 "CONSTITUCIONAL. RECURSO EXTRAORDINÁRIO. PRINCÍPIO CONSTITUCIONAL DA PRESUNÇÃO DE INOCÊNCIA (CF, ART. 5०, LVII). ACÓRDÃO PENAL CONDENATÓRIO. EXECUÇÃO PROVISÓRIA. POSSIBILIDADE. REPERCUSSÃO GERAL RECONHECIDA. JURISPRUDÊNCIA REAFIRMADA. 1. Em regime de repercussão geral, fica reafirmada a jurisprudência do Supremo Tribunal Federal no sentido de que a execução provisória de acórdão penal condenatório proferido em grau recursal, ainda que sujeito a recurso especial ou extraordinário, não compromete o princípio constitucional da presunção de inocência afirmado pelo artigo $5^{\circ}$, inciso LVII, da Constituição Federal. 2. Recurso extraordinário a que se nega provimento, com o reconhecimento da repercussão geral do tema e a reafirmação da jurisprudência sobre a matéria." (ARE 964246 RG, Rel. Min. Teori Zavascki, julgado em 10/11/2016, REPERCUSSÃO GERAL - MÉRITO DJe 25-11-2016.)

${ }^{29}$ Parte da doutrina critica severamente a viragem jurisprudencial por contravir claramente ao texto expresso da Constituição. Nesse sentido, cf. MEYER-PFLUG, Samantha Ribeiro; COUTO, Mônica Bonetti. A presunção de inocência, a constituição e o STF: comentários ao HC 126.292/SP. Revista de Direito Brasileira, São Paulo, v. 15, n. 6, p. 399-405, set./dez. 2016.
}

Revista de Direito Brasileira | São Paulo, SP | v. 19 | n. 8 | p. 348 - 365 |Jan./Abr. 2018 
estará compelida desde logo a observar tal decisão, pese embora a ausência de seu trânsito em julgado, ou se tal vinculação somente surgirá com o aludido trânsito em julgado.

No referido julgamento, o STF tratou a presunção de inocência como norma-princípio - e não mais como norma-regra, como fizera no julgamento da Lei da Ficha Limpa - , a fim de flexibilizar sua aplicação mediante ponderação com outros princípios e bens constitucionais colidentes, à consideração de que a presunção de culpabilidade vai gradativamente perdendo vigor e peso à proporção que as condenações se vão sucedendo. ${ }^{30}$

Certo é que a doutrina ${ }^{31}$ e a jurisprudência majoritárias vêm exigindo o trânsito em julgado da condenação criminal para que esta possa obrigar a autoridade administrativa. Todavia, essa exigência derivava, em grande medida, da exegese até então emprestada ao princípio constitucional da não culpabilidade (CF/88, art. 5. ${ }^{\circ}$, LVII $) .^{32}$

De feito, não há na Lei n. ${ }^{\circ}$ 8.112/90, nem nos Códigos Penal, Civil e Processual Penal, nenhum dispositivo que condicione expressamente a observância da decisão criminal condenatória no âmbito administrativo ao seu trânsito em julgado.

É verdade que o art. 63 do CPP exige o trânsito em julgado da sentença penal condenatória, mas para sua execução na esfera cível, isto é, para efeito de reparação do dano civil causado, nada dispondo acerca da instância administrativa. Esse condicionamento ao trânsito em julgado é perfeitamente razoável e ajustado a essa finalidade específica, porquanto, nessa hipótese, a sentença condenatória passada em julgado servirá de título executivo para a execução da reparação do dano civil, não sendo recomendável uma execução provisória desses valores.

Por sua vez, o art. 92, I, do $\mathrm{CP}$ atribui à sentença condenatória criminal efeitos nas órbitas civil e administrativa, dentre os quais "a perda de cargo, função pública ou mandato eletivo", mas não alude expressamente à necessidade de trânsito em julgado.

De sua parte, o art. 935 do CC/2002 não menciona trânsito em julgado, preceituando que a autoria e a existência do fato não poderão ser rediscutidas na esfera civil se "se acharem decididas no juízo criminal". ${ }^{33}$ Como se vê, para além de não exigir explicitamente o trânsito em julgado (não reclama que tais questões tenham sido definitivamente decididas no juízo criminal),

\footnotetext{
${ }^{30}$ Esse modo de ver é bastante explícito no voto do Min. Barroso: “(ii) a presunção de inocência é princípio (e não regra) e, como tal, pode ser aplicada com maior ou menor intensidade, quando ponderada com outros princípios ou bens jurídicos constitucionais colidentes. No caso específico da condenação em segundo grau de jurisdição, na medida em que já houve demonstração segura da responsabilidade penal do réu e finalizou-se a apreciação de fatos e provas, o princípio da presunção de inocência adquire menor peso ao ser ponderado com o interesse constitucional na efetividade da lei penal para a proteção dos bens jurídicos tutelados pelo direito penal, como a vida, a segurança e a integridade física e moral das pessoas (CF/1988, arts. 5, caput e LXXVIII e 144)". (ARE 964246 RG, Rel. Min. Teori Zavascki, julgado em 10/11/2016, REPERCUSSÃO GERAL - MÉRITO DJe 25-11-2016.)

${ }^{31}$ Cf., inter alia: SCHMITT, Ricardo Augusto. Sentença penal condenatória: teoria e prática. 7. ed. Salvador: JusPodivm, 2012, p. 471. DELMANTO, Celso et al. Código Penal comentado. 9. ed. São Paulo: Saraiva, 2016 , p. 338. PRADO, Luiz Regis. Comentários ao Código Penal. 10. ed. São Paulo: RT, 2015, p. 414 e segs. MIRABETE, Julio Fabbrini; MIRABETE, Renato N. Fabbrini. Código Penal interpretado. 9. ed. São Paulo: Atlas, 2015, p. 564565. MASSON, Cleber. Código Penal comentado. 3. ed. São Paulo: Método, 2015, p. 425.

32 "A executoriedade da sentença penal condenatória (CPP, art. 63) ou seu aproveitamento em ação civil ex delicto (CPP, art. 64; CPC, arts. 110 e 265, IV) depende da definitividade da condenação, ou seja, da formação da coisa julgada criminal, até mesmo pela máxima constitucional de que ninguém poderá ser considerado culpado antes do trânsito em julgado de sentença penal condenatória (CF, art. $5^{\circ}$, LVII). 2. Na hipótese em exame, a sentença penal condenatória não transitou em julgado para a defesa, pois foi, supervenientemente, substituída por acórdão em apelação criminal que extinguiu a punibilidade, em decorrência do reconhecimento da prescrição retroativa. 3. A sentença penal condenatória, não transitada em julgado, não possibilita a excepcional comunicabilidade entre o juízo cível e o criminal, prevista no art. 1.525 do Código Civil de 1916 (atual art. 935 do Código Civil de 2002) e nos arts. 63 e 65 do Código de Processo Penal. [...]" (REsp 678.143/MG, Rel. Min. Raul Araújo, 4a turma, julgado em 22/05/2012, DJe 30/04/2013.) (Grifou-se.)

33 “Art. 935. A responsabilidade civil é independente da criminal, não se podendo questionar mais sobre a existência do fato, ou sobre quem seja o seu autor, quando estas questões se acharem decididas no juízo criminal."
}

Revista de Direito Brasileira | São Paulo, SP | v. 19 | n. 8 | p. 348 - 365 |Jan./Abr. 2018 
não alude expressamente à esfera administrativa, versando unicamente de responsabilidade civil (até porque se trata de norma inserida no Código Civil).

O próprio Enunciado n. ${ }^{\circ} 45$ das Jornadas de Direito Civil do CJF ("No caso do art. 935, não mais se poderá questionar a existência do fato ou quem seja o seu autor se essas questões se acharem categoricamente decididas no juízo criminal"), apesar de empregar o advérbio "categoricamente", não esclarece se este concerne à suficiência da prova (a depender, portanto, do enquadramento nos incisos do art. 386 do $\mathrm{CPP}^{34}$ ), à imutabilidade da decisão pelo trânsito em julgado, ou a ambos cumulativamente. ${ }^{35}$

O requisito do trânsito em julgado só aparece na legislação extravagante, o que, aparentemente, serviria para confirmar seu caráter excepcional. É o caso, e. g., do art. $2 .^{\circ}, \S 6 .^{\circ}$, da Lei n. ${ }^{\circ}$ 12.850/2013 (que trata das organizações criminosas), o qual condiciona explicitamente ao trânsito em julgado "a perda do cargo, função, emprego ou mandato eletivo e a interdição para o exercício de função ou cargo público pelo prazo de 8 (oito) anos subsequentes ao cumprimento da pena." $" 36$

A Lei 7.716/89 (que trata dos "crimes resultantes de preconceito de raça ou de cor") estabelece - em redação simílima à do art. 92, I, do Código Penal — como efeito extrapenal da condenação a perda do cargo ou função pública, para o servidor público, sem alusão a trânsito em julgado (art. 16 e 18). ${ }^{37}$ Contudo, logo em seguida, ao tratar da destruição do material apreendido (outro efeito da condenação), condiciona-a expressamente ao trânsito em julgado da decisão condenatória. $^{38}$

Portanto, poder-se-ia argumentar que quando a lei penal quis distinguir, assim o fez. Destarte, "ubi lex non distinguit, nec nos distinguere debemus": onde a lei não distingue, não caberia ao intérprete [ou à Administração Pública] fazê-lo.

Todavia, esta não parece ser a melhor interpretação, à luz do texto constitucional brasileiro e do direito comparado.

Com efeito, independentemente da exegese dada ao art. 5. ${ }^{\circ}$, LVII, não há olvidar o previsto no art. $41, \S 1 .^{\circ}$, da $\mathrm{CF} / 88$, segundo o qual o servidor estável somente pode perder o cargo mediante processo administrativo em que lhe seja assegurada ampla defesa ou em virtude de "sentença judicial transitada em julgado".39

\footnotetext{
${ }^{34}$ Por exemplo, "estar provada a inexistência do fato" (inciso I) difere de "não haver prova da existência do fato" (inciso II). No primeiro caso, há uma certeza acerca da inexistência do fato, ao passo que no segundo caso essa certeza inexiste, razão pela qual Maria Sylvia Di Pietro, dentre outros, como visto acima, afirma que só há repercussão na esfera administrativa na primeira hipótese (inciso I).

${ }^{35}$ Sem fazer alusão ao grau de suficiência da prova acerca da existência do fato e da autoria (nos moldes do art. 386 do CPP), mas exigindo o trânsito em julgado: "Embora o Enunciado não fale em coisa julgada, na verdade somente depois de transitada em julgado a sentença penal é que as questões terão sido 'categoricamente decididas' no juízo criminal. Daí por que, quanto à materialidade e autoria, a sentença penal transitada em julgado faz coisa julgada na esfera cível." (NERY JUNIOR, Nelson; NERY, Rosa Maria de Andrade. Código Civil comentado. 11. ed. São Paulo: RT, 2014, p. 1245.)

36 “Art. $2^{\mathrm{o}}$ [...] $§ 6^{\mathrm{O}}$ A condenação com trânsito em julgado acarretará ao funcionário público a perda do cargo, função, emprego ou mandato eletivo e a interdição para o exercício de função ou cargo público pelo prazo de 8 (oito) anos subsequentes ao cumprimento da pena."

37 “Art. 16. Constitui efeito da condenação a perda do cargo ou função pública, para o servidor público, e a suspensão do funcionamento do estabelecimento particular por prazo não superior a três meses. [...]

Art. 18. Os efeitos de que tratam os arts. 16 e 17 desta Lei não são automáticos, devendo ser motivadamente declarados na sentença."

38 “Art. 20. [...] $\S 4^{\circ} \mathrm{Na}$ hipótese do $\S 2^{\circ}$, constitui efeito da condenação, após o trânsito em julgado da decisão, a

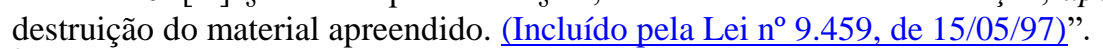

39 “Art. 41. São estáveis após três anos de efetivo exercício os servidores nomeados para cargo de provimento efetivo em virtude de concurso público. (Redação dada pela EC n 19, de 1998)

$\S 1^{\circ} \mathrm{O}$ servidor público estável só perderá o cargo: (Redação dada pela EC nº 19, de 1998)

I - em virtude de sentença judicial transitada em julgado; (Incluído pela EC n 19, de 1998)

II - mediante processo administrativo em que lhe seja assegurada ampla defesa; (Incluído pela EC n 19, de 1998)
}

Revista de Direito Brasileira | São Paulo, SP | v. 19 | n. 8 | p. 348 - 365 |Jan./Abr. 2018 
Interpretando o art. 92, I, do Código Penal à sombra dessa norma constitucional, inferese claramente que, ao menos no que concerne aos servidores estáveis, a perda do cargo em decorrência de sentença penal condenatória só ocorrerá com o trânsito em julgado desta.

Por outro lado, a perda do mandato eletivo do Deputado ou do Senador em razão de sentença penal condenatória também não prescinde de trânsito em julgado, conforme exige expressamente o art. 55 , VI, da $\mathrm{CF} / 88$. $^{40}$

A seu turno, no direito espanhol, somente as decisões criminais passadas em julgado ("firmes") vinculam a decisão no processo administrativo, consoante prescreve o art. 137.2 da Lei n. 30/1992 (Ley de Régimen Jurídico de las Administraciones Públicas y del Procedimiento Administrativo Común - LRJPAC). ${ }^{41}$ Há vários precedentes do Tribunal Constitucional espanhol a corroborar essa disposição legal, ainda que inexplicitamente. ${ }^{42}$

Por sua vez, o art. 653 do Código de Processo Penal italiano é claro ao estatuir que só as sentenças penais de absolvição e de condenação "irrevogáveis" (transitadas em julgado) vinculam as autoridades administrativas quanto à (in)existência material do fato, à autoria e à ilicitude penal. $^{43}$

De outra parte, poder-se-ia sustentar ainda que o acórdão penal condenatório ainda não transitado em julgado vincula a decisão na instância administrativa, visto que, se a sanção mais gravosa (pena privativa de liberdade) pode ter aplicação imediata, a fortiori deve ter aplicação imediata a sanção mais branda (punição administrativa disciplinar).

III - mediante procedimento de avaliação periódica de desempenho, na forma de lei complementar, assegurada ampla defesa. (Incluído pela EC n 19, de 1998)"

40 "Art. 55. Perderá o mandato o Deputado ou Senador: [...] VI - que sofrer condenação criminal em sentença transitada em julgado." (Grifou-se.)

41 "Artículo 137. Presunción de inocencia. [...] 2. Los hechos declarados probados por resoluciones judiciales penales firmes vincularán a las Administraciones Públicas respecto de los procedimientos sancionadores que substancien." (Grifou-se.)

${ }^{42}$ Cf., dentre outras, as Sentencias 77/1983, 62/1984, 158/1985 e 172/2016. Na STC 77/1983, afirmou o Tribunal Constitucional espanhol: "La cosa juzgada despliega un efecto positivo, de manera que lo declarado por Sentencia firme constituye la verdad jurídica y un efecto negativo, que determina la imposibilidad de que se produzca un nuevo pronunciamiento sobre el tema", porquanto "es claro que unos mismos hechos no pueden existir y dejar de existir para los órganos del Estado". Na STC 172/2016, essa mesma rationale é retomada e desenvolvida: "Por lo que se refiere al principio de intangibilidad de las resoluciones judiciales firmes y su incidencia en el derecho a la tutela judicial efectiva, que es lo concretamente planteado por el recurrente y a lo que se debe limitar el control de constitucionalidad, el Tribunal Constitucional ha venido afirmando desde antiguo que 'si el respeto a la independencia de cada órgano judicial es principio básico de nuestro ordenamiento jurídico, no es menos cierto que unos mismos hechos no pueden existir y dejar de existir para los órganos del Estado (STC 77/1983, de 3 de octubre), y que esta negación del principio de contradicción vulnera el derecho a la tutela judicial efectiva consagrado en el art. 24.1 de la Constitución Española' (STC 158/1985, de 26 de noviembre, FJ 4). En desarrollo de esa idea, la STC 158/1985, remitiéndose a la STC 62/1984, de 21 de mayo, FJ 5, establecía que a 'los más elementales criterios de la razón jurídica repugna aceptar la firmeza de distintas resoluciones judiciales en virtud de las cuales resulte que unos mismos hechos ocurrieron y no ocurrieron, o que una misma persona fue su autor y no lo fue. Ello vulneraría, en efecto, el principio de seguridad jurídica que, como una exigencia objetiva del ordenamiento, se impone al funcionamiento de todos los órganos del Estado en el art. 9.3 CE. Pero, en cuanto dicho principio integra también la expectativa legítima de quienes son justiciables a obtener para una misma cuestión una respuesta inequívoca de los órganos encargados de impartir justicia, ha de considerarse que ello vulneraría, asimismo, el derecho subjetivo a una tutela jurisdiccional efectiva, reconocido por el art. 24.1 CE, pues no resulta compatible la efectividad de dicha tutela y la firmeza de pronunciamientos judiciales contradictorios.' (STC 158/1985, FJ 4).”

43 “Art. 653. Efficacia della sentenza penale nel giudizio disciplinare

1. La sentenza penale irrevocabile di assoluzione ha efficacia di giudicato nel giudizio per responsabilità disciplinare davanti alle pubbliche autorità quanto all'accertamento che il fatto non sussiste o non costituisce illecito penale ovvero che l'imputato non lo ha commesso.

1-bis. La sentenza penale irrevocabile di condanna ha efficacia di giudicato nel giudizio per responsabilità disciplinare davanti alle pubbliche autorità quanto all'accertamento della sussistenza del fatto, della sua illiceità penale e all'affermazione che l'imputato lo ha commesso." (Grifou-se.)

Revista de Direito Brasileira | São Paulo, SP | v. 19 | n. 8 | p. 348 - 365 |Jan./Abr. 2018 
Ocorre que a regra é a da independência (ainda que relativa) das instâncias, de modo que, inexistindo norma legal que confira eficácia vinculante à decisão criminal na esfera administrativa, remanesce intacta a autonomia decisória da autoridade administrativa. A independência das instâncias é dita "relativa" exatamente porque a lei excepciona, em determinadas hipóteses específicas, essa natural independência. A independência (= não comunicabilidade) é a regra, a comunicabilidade é a exceção. É o que se infere de uma interpretação sistemática do ordenamento pátrio, designadamente do disposto nos arts. $37, \S 4^{\circ}$, e 225 da CF/88 e no art. 125 da Lei 8.112/90. Logo, não havendo exceção legalmente prevista, impondo a comunicação entre as instâncias, prevalece a independência das respectivas instâncias.

No caso, não há norma legal a determinar a comunicação de instâncias por força da mera condenação criminal em $2^{\mathrm{a}}$ instância, ainda sujeita a recurso, de maneira que persiste íntegra a independência da instância administrativa.

Malgrado o acórdão condenatório não vincule a decisão na órbita administrativa antes do seu trânsito em julgado, nada impede que, nesse entretempo, a prova produzida no juízo criminal seja utilizada como prova emprestada no processo administrativo, servindo para lastrear a decisão administrativa disciplinar, consoante autoriza a jurisprudência do STF.

Ademais, os fundamentos e as conclusões a que chegou o acórdão penal condenatório, após serem contrasteados e sopesados pela autoridade administrativa, poderão auxiliar na formação do convencimento desta e, se for o caso, corroborar o juízo formulado na via administrativa, suavizando o ônus argumentativo que pesa sobre a autoridade administrativa, enfraquecida como estará a presunção de não culpabilidade após uma condenação criminal em $2^{\mathrm{a}}$ instância.

De feito, se a presunção de não culpabilidade vai esvaindo-se à medida que se somam novas condenações em instâncias judiciais sucessivas, a ponto de permitir o início do cumprimento da pena de prisão antes do trânsito em julgado, com maioria de razão esse esmaecimento progressivo da presunção de não culpabilidade ensejaria uma redução do ônus argumentativo da autoridade administrativa para inflição de uma pena bem menos gravosa do que a de prisão, como a pena administrativa de perda do cargo.

Inversamente, o ônus argumentativo para absolvição na via administrativa aumenta sensivelmente à medida que se sucedem decisões condenatórias no juízo criminal. A fundamentação adotada na decisão administrativa absolutória proferida quando já há condenação criminal em $2^{\text {a }}$ instância há de ser suficientemente robusta, convincente e analítica para refutar, um a um, todos os fundamentos em que amparado o acórdão criminal condenatório.

É certo que assiste ainda à Administração a faculdade (e não a obrigação, como se viu) de suspender o processo administrativo disciplinar à espera do trânsito em julgado do acórdão penal condenatório, à consideração, por exemplo, da necessidade da força de trabalho daquele servidor (princípio da continuidade do serviço público) ${ }^{44}$ e da possibilidade de reintegração do servidor em caso de absolvição na via judicial, com pagamento da remuneração alusiva ao período de afastamento mesmo sem a prestação do trabalho, bem assim, em sendo o caso, de

\footnotetext{
${ }^{44}$ Obviamente, pressupõe-se, no exemplo, que o regime de cumprimento da pena privativa de liberdade permita o trabalho do servidor, de modo que, mesmo iniciado o cumprimento da pena em razão da condenação em $2^{\mathrm{a}}$ instância, o labor do servidor não ficou inviabilizado, considerando-se ainda que a perda do cargo só ocorrerá com o trânsito em julgado. A este respeito, conferir o disposto nos arts. 34 e seguintes do Código Penal e nos arts. 36 e seguintes da Lei de Execuções Penais-LEP. É de salientar que o Plenário do STF já afastou a exigência do art. 37 da LEP de cumprimento de $1 / 6$ da pena para ensejar o trabalho externo do condenado em regime semiaberto: "EXECUÇÃO PENAL. REGIME INICIAL SEMIABERTO. TRABALHO EXTERNO. 1. A exigência objetiva de prévio cumprimento do mínimo de um sexto da pena, segundo a reiterada jurisprudência do Superior Tribunal de Justiça, não se aplica aos presos que se encontrem em regime inicial semiaberto. Diversos fundamentos se conjugam para a manutenção desse entendimento. [...]." (EP 2 TrabExt-AgR, Rel. Min. Roberto Barroso, Tribunal Pleno, julgado em 25/06/2014, DJe 30-10-2014.)
} 
eventuais despesas decorrentes da colocação de outro servidor em disponibilidade remunerada, conforme dispõe o art. $41, \S 2$. ${ }^{\circ}$, da $\mathrm{CF} / 88 .{ }^{45}$

Todavia, os dados estatísticos não podem ser menosprezados pela autoridade administrativa. Estes evidenciam claramente que o índice de reforma dos acórdãos condenatórios para acórdãos absolutórios é bastante reduzido. Segundo dados do STF e da FGV, de 2009 a 2016, o número de agravos e recursos extraordinários providos em favor do réu foi inferior a $1,5 \%$ e o número de habeas corpus providos foi de cerca de $16 \%$. Releva observar, porém, que a esmagadora maioria desses provimentos não importou em absolvição do réu, mas apenas em modificação da dosimetria da pena, do regime inicial de cumprimento da pena, etc.

Levando em consideração apenas os recursos e habeas corpus manejados pela Defensoria Pública, confiram-se os dados colacionados pelo Min. Teori Zavascki:

Dos processos distribuídos ao STF no período de 2009 a 2016 (período em que se afirmou a impossibilidade de execução provisória da pena), houve um total de 22.610 recursos criminais. Desses, foram interpostos pela Defensoria Pública 2.585 REs, AREs e AIs, ou seja, apenas 11,43\%. E desses, apenas 1,54\% alcançaram provimento, sendo que, isso é importante, invariavelmente envolvendo matéria não relacionada à culpabilidade do acusado (em geral, prescrição e obrigatoriedade do regime fechado para crime hediondo, matérias que poderiam, com maior celeridade e eficiência, ser suscitadas em habeas corpus). Aliás, nesse mesmo período, a Defensoria Pública foi responsável pela impetração de 10.712 habeas corpus, das quais $16,15 \%$ foram concedidos, pelo menos parcialmente. [...]

Relativamente aos temas com maior incidência, destacou-se a fixação do regime inicial de cumprimento de pena, o erro na dosimetria da pena, a prisão cautelar, a aplicação do princípio da insignificância e o excesso de prazo da prisão, ou seja, matérias majoritariamente atreladas à prisão cautelar ou às circunstâncias do cumprimento da pena. [...] A culpabilidade propriamente raramente é objeto de questionamento e muito menos de - acolhimento pouco reformada nas instâncias extraordinárias. (ARE 964246 RG, Rel. Min. Teori Zavascki, julgado em 10/11/2016, REPERCUSSÃO GERAL - MÉRITO, DJe 25-11-2016.)

Ademais, consoante dados da FGV, as taxas de sucesso em habeas corpus são ínfimas em casos de crimes cometidos por servidor contra a Administração Pública. O peculato, por exemplo, é o único a ultrapassar (em pouco) $10 \%$ de taxa de reversão, e, mesmo assim, considerando-se qualquer espécie de provimento (total ou parcial) do habeas corpus e que a grande maioria desses provimentos não conduz à absolvição. ${ }^{46}$

Portanto, malgrado a inexistência de vinculação formal ao acórdão condenatório ainda não passado em julgado, estima-se que, na prática, diante (a) do elevado ônus argumentativo necessário para sobrepujar os fundamentos do acórdão e (b) da diminuta taxa de reforma dos acórdãos condenatórios para absolutórios, a tendência da autoridade administrativa seja a de aderir às razões acolhidas no acórdão.

\footnotetext{
45 “Art. 41. [...] $\S 2^{\circ}$ Invalidada por sentença judicial a demissão do servidor estável, será ele reintegrado, e o eventual ocupante da vaga, se estável, reconduzido ao cargo de origem, sem direito a indenização, aproveitado em outro cargo ou posto em disponibilidade com remuneração proporcional ao tempo de serviço. (Redação dada pela EC $\mathrm{n}^{\circ} 19$, de 1998)"

${ }^{46}$ Cf. o relatório final do projeto "Panaceia universal ou remédio constitucional? Habeas Corpus nos Tribunais Superiores". Disponível em: 〈http://direitorio.fgv.br/projetos/habeas-corpus-nos-tribunais-superiores〉. Acesso em: 19 jan. 2017.
} 


\section{CONCLUSÃO}

A independência das instâncias penal, civil e administrativa não é absoluta, mas relativa, razão pela qual há várias repercussões recíprocas. A decisão na instância administrativa pode repercutir decisivamente na instância penal, como, por exemplo, sucede com a decisão da Receita Federal sobre a validade do lançamento tributário nos crimes contra a ordem tributária: se o lançamento for anulado pela Receita, desaparece a própria tipicidade da conduta, não podendo haver mais discussão na esfera penal sobre a existência do crime (inteligência da Súmula Vinculante $n^{\circ} 24$ do STF: "Não se tipifica crime material contra a ordem tributária, previsto no art. $1^{\circ}$, incisos I a IV, da Lei $n^{\circ} 8.137 / 90$, antes do lançamento definitivo do tributo").

Todavia, as repercussões das decisões proferidas na instância penal sobre os processos administrativos são bem mais recorrentes na prática.

Em apertada síntese, pode-se afirmar que as sentenças penais condenatórias sempre repercutem na esfera administrativa, ao passo que as absolutórias repercutem quando negam a materialidade do fato, sua autoria, ou reconhecem a ocorrência de causas excludentes de antijuridicidade ou de eximentes de pena.

Conquanto seja possível (e até mesmo conveniente em determinados casos) a suspensão do processo administrativo enquanto a existência do crime não é decidida no juízo criminal, a Administração não está obrigada a sobrestar o processo administrativo, consoante entendimento pacificado pelo STF em RE com repercussão geral, sem que isto importe em vulneração ao princípio constitucional da presunção de inocência, cujo âmbito de incidência, ainda segundo o STF, se adstringe ao direito penal.

No julgamento da Lei da Ficha Limpa, o STF tratou a presunção de inocência como norma-regra (passível de redução teleológica), ao passo que no julgamento alusivo à prisão em virtude de condenação criminal em segunda instância tratou-a como norma-princípio, com o objetivo de flexibilizar sua aplicação mediante ponderação com outros princípios e bens constitucionais colidentes, considerando que a presunção de culpabilidade vai progressivamente perdendo peso e força à medida que as condenações se vão somando. Em ambos os casos, houve estreitamento do âmbito de proteção até então reconhecido ao direito fundamental consubstanciado na presunção de não culpabilidade, malgrado alcançado por métodos diversos (redução teleológica da norma-regra no caso da inelegibilidade, e ponderação de princípios no caso da prisão por condenação em segunda instância).

Todavia, o acórdão penal condenatório ainda não transitado em julgado não vincula a decisão na instância administrativa, que pode decidir diferentemente do juízo criminal, enquanto inexistir coisa julgada. A independência entre as instâncias (= não comunicabilidade) é a regra, ao passo que a comunicabilidade é a exceção. $\mathrm{Na}$ ausência de norma legal determinando a comunicação entre as instâncias penal e administrativa antes do trânsito em julgado, sobreleva a independência das respectivas instâncias. É certo, porém, que, em caso de absolvição ao final do processo criminal, esta repercutirá na esfera administrativa, com o retorno ao statu quo ante, anulando-se a pena disciplinar infligida e reintegrando-se o servidor, caso tenha sido demitido.

A despeito da ausência de vinculação formal ao acórdão condenatório ainda recorrível, prognostica-se que, na prática, a inclinação natural da autoridade administrativa seja a de associar-se às razões perfilhadas no acórdão, tendo em vista (a) o reforçado ônus argumentativo necessário para refutar os fundamentos do acórdão e (b) o escasso índice de reforma dos acórdãos condenatórios para absolutórios.

Nem sempre há total coincidência entre o ilícito penal e o administrativo, de modo que é perfeitamente possível que remanesça um ilícito administrativo puro (falta residual) após a absolvição do crime pela sentença penal, a possibilitar a punição do responsável na instância administrativa, nos moldes da súmula 18 do STF. 
A sentença penal condenatória e a sentença condenatória por ato de improbidade administrativa não repercutem no processo administrativo no tocante à pena de cassação de aposentadoria, mas, administrativamente, poderá haver a imposição da pena de cassação da aposentadoria, nos termos da Lei 8.112/90 ou da legislação estatutária estadual de regência.

$\mathrm{O}$ efeito principal da absolvição criminal comunicável na esfera administrativa é o de recompor os prejuízos e cancelar os efeitos de pena administrativa já imposta, restabelecendo o statu quo ante.

\section{REFERÊNCIAS BIBLIOGRÁFICAS}

ALEXY, Robert. Teoria dos direitos fundamentais. Trad. Virgílio Afonso da Silva. São Paulo: Malheiros, 2008.

AMARAL, Thiago Bottino do. Panaceia universal ou remédio constitucional? Habeas Corpus nos Tribunais Superiores. Disponível em: <http://direitorio.fgv.br/projetos/habeas-corpus-nostribunais-superiores>. Acesso em: 19 jan. 2017.

ARAÚJO, Edmir Netto de. Curso de Direito Administrativo. 7. ed. São Paulo: Saraiva, 2015.

ÁVILA, Humberto. Teoria dos princípios: da definição à aplicação dos princípios jurídicos. 14. ed. São Paulo: Malheiros, 2013.

BACELLAR FILHO, Romeu Felipe. O Mensalão e a propalada independência das instâncias. Revista dos Tribunais, São Paulo, v. 933, p. 445-454, jul. 2013.

BRASIL, Deilton Ribeiro. A garantia do princípio constitucional da presunção de inocência (ou de não culpabilidade): um diálogo com os direitos e garantias fundamentais. Revista de Direito Brasileira, São Paulo, v. 15, n. 6, p. 376-398, set./dez. 2016.

CASETTA, Elio. Manuale di diritto amministrativo. 13. ed. Milano: Giuffrè, 2011.

CRETELLA JÚNIOR, José. Do ilícito administrativo. Disponível em: <http://www.revistas.usp.br/rfdusp/article/viewFile/66693/69303>. Acesso em: 17 jan. 2017.

DELMANTO, Celso et al. Código Penal comentado. 9. ed. São Paulo: Saraiva, 2016.

DI GIACOMO, Lorenzo. Gli incidenti nel processo e l'estinzione del giudizio. In: FRENI, Federico: CLARIZIA, Paolo (Coords.). Il processo amministrativo nella giurisprudenza. Commento sistematico ai principali istituti. Testo aggiornato al decreto correttivo al Codice del Processo Amministrativo (d.lgs. 15 novembre 2011, n.195). Milano: Giuffrè, 2012.

DI PIETRO, Maria Sylvia Zanella. Curso de Direito Administrativo. 28. ed. São Paulo: Atlas, 2015.

MASSON, Cleber. Código Penal comentado. 3. ed. São Paulo: Método, 2015.

MEIRELLES, Hely Lopes. Curso de Direito Administrativo brasileiro. 38. ed. São Paulo: Malheiros, 2012. 
MEYER-PFLUG, Samantha Ribeiro; COUTO, Mônica Bonetti. A presunção de inocência, a constituição e o STF: comentários ao HC 126.292/SP. Revista de Direito Brasileira, São Paulo, v. 15, n. 6, p. 399-405, set./dez. 2016.

MIRABETE, Julio Fabbrini; MIRABETE, Renato N. Fabbrini. Código Penal interpretado. 9. ed. São Paulo: Atlas, 2015.

NERY JUNIOR, Nelson; NERY, Rosa Maria de Andrade. Código Civil comentado. 11. ed. São Paulo: RT, 2014.

NUCCI, Guilherme de Souza. Código Penal comentado. 10. ed. São Paulo: RT, 2010.

PRADO, Luiz Regis. Comentários ao Código Penal. 10. ed. São Paulo: RT, 2015.

SCHMITT, Ricardo Augusto. Sentença penal condenatória: teoria e prática. 7. ed. Salvador: JusPodivm, 2012.

SILVA, Virgílio Afonso da. Direitos fundamentais: conteúdo essencial, restrições e eficácia. 2. ed. São Paulo: Malheiros, 2014. 